\title{
1 Predictors of postoperative biochemical remission in acromegaly
}

2 Shun Yao, MD, PhD,${ }^{1,2^{*}}$ Wen-Li Chen, MD ${ }^{1 *}$ Sherwin Tavakol, MPH, ${ }^{2,3}$ Farhana Akter, MD ${ }^{4,5}$

3 Michael P. Catalino, MD, MSc, ${ }^{2,6}$ Jie luo, BS, ${ }^{7,8}$ Xiao-Peng Guo, MD, PhD, ${ }^{9}$ Ai-Liang Zeng,

$4 \quad \mathrm{MD}, \mathrm{PhD},{ }^{10}$ Leo Zekelman, BA, ${ }^{11}$ Zhi-Gang Mao, MD, PhD, ${ }^{1}$ Yong-Hong Zhu, PhD, ${ }^{12}$ Qing-Zhi

$5 \mathrm{Wu}, \mathrm{PhD},{ }^{13}$ Edward R Laws, Jr, MD, FACS, ${ }^{2}$ Wenya Linda Bi, MD, PhD,${ }^{2 \#}$ Hai-Jun Wang, MD, $6 \mathrm{PhD}^{1 \#}$

$7 \quad{ }^{1}$ Center for Pituitary Tumor Surgery, Department of Neurosurgery, The First Affiliated Hospital,

8 Sun Yat-sen University, Guangzhou, Guangdong, China

$9 \quad{ }^{2}$ Center for Skull Base and Pituitary Surgery, Department of Neurosurgery, Brigham and

10 Women's Hospital, Harvard Medical School, Boston, Massachusetts, USA

$11{ }^{3}$ Department of Neurological Surgery, Keck School of Medicine, University of Southern

12 California, Los Angeles, California, USA

$13 \quad{ }^{4}$ Faculty of Arts and Sciences, Harvard University, Cambridge, Massachusetts, USA

$14{ }^{5}$ Department of Neuroscience, University of Cambridge, Cambridge, UK

$15{ }^{6}$ Department of Neurosurgery, University of North Carolina, Chapel Hill, North Carolina, USA

$16{ }^{7}$ Surgical Planning Laboratory, Department of Radiology, Brigham and Women's Hospital,

17 Harvard Medical School, Boston, Massachusetts, USA

$18{ }^{8}$ Department of Complexity Science and Engineering, Graduate School of Frontier Sciences,

19 The University of Tokyo, Tokyo, Japan

$20{ }^{9}$ Department of Neurosurgery, Peking Union Medical College Hospital, Chinese Academy of

21 Medical Sciences and Peking Union Medical College, Beijing, China

$22{ }^{10}$ Department of Cancer Biology, University of Texas MD Anderson Cancer Center, Houston,

23 Texas, USA

NOTE: This preprint reports new research that has not been certified by peer review and should not be used to guide clinical practice. 1 
medRxiv preprint doi: https://doi.org/10.1101/2020.06.26.20141325; this version posted July 27, 2020. The copyright holder for this preprint (which was not certified by peer review) is the author/funder, who has granted medRxiv a license to display the preprint in perpetuity.

It is made available under a CC-BY-NC-ND 4.0 International license .

$24{ }^{11}$ Speech and Hearing Bioscience and Technology, Harvard University, Cambridge,

25 Massachusetts, USA

$26{ }^{12}$ Department of Histology and Embryology, Zhongshan School of Medicine, Sun Yat-Sen

27 University, Guangzhou, Guangdong, China

$28{ }^{13}$ State Key Laboratory of Advanced Technology for Materials Synthesis and Processing,

29 Wuhan University of Technology, Wuhan, Hubei, China

30 *Shun Yao and Wen-Li Chen contributed equally to the work.

31 Disclosure: Leo Zekelman received funding from National Institute of Health (NIH) Ruth L.

32 Kirschstein National Research Service Award (T32DC000038-27).

33 Financial support: This work was supported by the funding to SY through the Chinese

34 Postdoctoral Science Foundation (2019M663271) and the Chinese Scholarship Council

35 (201808440461), Guangzhou Science and Technology Project (201704020085) to HJW.

37 Co-corresponding authors

38 Wenya Linda Bi, M.D., Ph.D.

39 Assistant Professor

40 Department of Neurosurgery, Brigham and Women's Hospital, Harvard Medical School

4160 Fenwood Road, MA 02115, United States

42 Email: wbi@bwh.harvard.edu|Tel: +1 (617) 525-8319

43 Hai-Jun Wang, M.D., Ph.D.

44 Chairman and Professor

45 Department of Neurosurgery, The First Affiliated Hospital, Sun Yat-sen University 
medRxiv preprint doi: https://doi.org/10.1101/2020.06.26.20141325; this version posted July 27, 2020. The copyright holder for this preprint (which was not certified by peer review) is the author/funder, who has granted medRxiv a license to display the preprint in perpetuity. It is made available under a CC-BY-NC-ND 4.0 International license .

4658 Zhongshan 2nd Rd, Yuexiu District, Guangzhou 510080, Guangdong, China

47 Email: wanghaij@ mail.sysu.edu.cn | Tel: +86-138 26199966

48 
medRxiv preprint doi: https://doi.org/10.1101/2020.06.26.20141325; this version posted July 27, 2020. The copyright holder for this preprint (which was not certified by peer review) is the author/funder, who has granted medRxiv a license to display the preprint in perpetuity.

It is made available under a CC-BY-NC-ND 4.0 International license .

\section{ABSTRACT}

50 OBJECTIVE

51 Acromegaly is a rare neuroendocrine condition that can lead to significant morbidity; therefore,

52 large studies are invaluable for understanding the disease burden. Despite China's vast

53 population size, studies on acromegaly remain sparse. In this report, we aimed to investigate

54 clinical characteristics and predictors of biochemical remission after surgery for acromegaly.

\section{METHODS}

56 A retrospective nationwide study was conducted using patient-reported data from the China

57 Acromegaly Patient Association (CAPA) from 1998 to 2018. Univariate analyses were

58 performed using Wilcoxon rank-sum tests, two-sample t-tests, and chi-squared tests. Using the

59 purposeful selection method, multivariate logistic regression analysis was employed to determine

60 independent predictors of biochemical remission at 3 months in patients after surgery.

61 RESULTS: Of the 575 cases (mean age: 37.3 years; $59 \%$ female), macroadenomas and invasive

62 tumors (Knosp score 3-4) were $87 \%$ and 61\%, respectively. Ninety-five percent of patients were

63 treated first with surgery (5.1\% transcranial and $94.9 \%$ endonasal) and $38.3 \%$ exhibited

64 biochemical remission at 3-months postoperatively. The following independent predictors of

65 biochemical remission were identified: preoperative growth hormone (GH) levels between 12

66 and $28 \mu \mathrm{g} / \mathrm{L}$ [odds ratio $(\mathrm{OR})=0.61 ; 95 \%$ confidence interval (CI), 0.39-0.96; $\mathrm{p}=0.031$ ],

67 preoperative $\mathrm{GH}$ levels $>28 \mu \mathrm{g} / \mathrm{L}(\mathrm{OR}=0.56 ; 95 \% \mathrm{CI}, 0.35-0.90 ; \mathrm{p}=0.016)$, macroadenoma

$68(\mathrm{OR}=0.57 ; 95 \% \mathrm{CI}, 0.33-0.97 ; \mathrm{p}=0.041)$, giant adenomas $(\mathrm{OR}=0.17 ; 95 \% \mathrm{CI}, 0.06-0.44$;

$69 \mathrm{p}=0.0005)$, Knosp score 3-4 (OR=0.39; 95\% CI, 0.25-0.59; $\mathrm{p}<0.0001)$, and preoperative

70 medication usage $(\mathrm{OR}=2.16 ; 95 \% \mathrm{CI}, 1.38-3.39 ; \mathrm{p}=0.0008)$. 
71 CONCLUSIONS: In this nationwide study spanning over two decades, we highlight that higher

72 preoperative GH levels, large tumor size, and greater extent of tumor invasiveness are associated

73 with a lower likelihood of biochemical remission at 3-months after surgery, while preoperative

74 medical therapy increases the chance of remission.

76 KEY WORDS: acromegaly, growth hormone, pituitary tumor, predictors, biochemical

77 remission

79 RUNNING TITLE: Postoperative remission predictors in acromegaly

81 ABBREVIATIONS

82 ACTH adrenocorticotropic hormone

83 CAPA China Acromegaly Patient Association

84 CI confidence interval

85 CT computed tomography

86 DA dopamine agonists

87 FDR family discovery rate

88 GH growth hormone

89 ICA internal carotid artery

90 IGF-1 insulin-like growth factor 1

91 LH, luteinizing hormone

92 IQR interquartile range

93 MRI high-resolution magnetic resonance imaging 
94 OR odds ratio

95 PRL prolactin (PRL),

96 FSH follicle stimulating hormone,

97 TSH, thyroid-stimulating hormone

98 VIF variance influence factor

99 SD standard deviation

100 SRLs somatostatin receptor ligands

\section{Introduction}

Acromegaly is a rare condition characterized by the overproduction of growth hormone

104 (GH) from a hypersecreting pituitary tumor. ${ }^{1-3}$ Clinical manifestations of GH-secreting tumors

105 can manifest insidiously and result in a delayed diagnosis, while the systemic repercussions of

106 insulin-like growth factor 1 (IGF-1) excess, resultant from GH stimulation, are associated with

107 increased morbidity and mortality. ${ }^{4}$ Symptoms and signs of acromegaly include facial changes,

108 excessive skeletal growth, soft tissue hypertrophy, obstructive sleep apnea, hyperhidrosis,

109 headache, and visual impairments. ${ }^{2,5-7}$ Persistent high levels of GH and/or IGF-1 may also result

110 in glucose intolerance, osteoporosis, arthritis, reproductive disorders, and cardiovascular

111 dysfunction, ultimately driving premature mortality. ${ }^{2,4-7}$

112 Given the rarity of acromegaly, large studies that characterize the disease

113 pattern, describe risk factors predictive of poor disease control and inform management decisions

114 of this condition are scarce. In particular, there is a notable gap in data regarding prevalence,

115 disease severity, treatments administered, and clinical outcomes for acromegaly patients in China.

116 We present the first report from the China Acromegaly Patient Association (CAPA), which is a 
medRxiv preprint doi: https://doi.org/10.1101/2020.06.26.20141325; this version posted July 27, 2020. The copyright holder for this preprint (which was not certified by peer review) is the author/funder, who has granted medRxiv a license to display the preprint in perpetuity.

It is made available under a CC-BY-NC-ND 4.0 International license .

117 non-profit, patient-advocacy organization with a patient-reported database encompassing

118 treatment from 112 hospitals. Using data from this directory, we aim to provide a comprehensive

119 description of clinical characteristics, and to identify predictors of biochemical remission at 3

120 months after surgery in patients with acromegaly in China, so as to improve recognition for the

121 diagnosis of acromegaly and to guide management decisions.

122

123 Methods

124

125 Study Design and Data Collection

We retrospectively reviewed the records of 916 acromegaly patients enrolled into the

128 multi-institutional China Acromegaly Patient Association (CAPA) database

129 (https://capa.wohenok.com) between June 1998 and December 2018. The CAPA database is

130 patient-reported and relies on the patient submission of demographic and clinical information

131 following the diagnosis and treatment of acromegaly, drawing upon patient information from

132112 hospitals across China (Supplemental Materials S1). Patients lacking data on treatment

133 interventions or biochemical status at follow-up were excluded from the analysis, resulting in a

134 final cohort of 575 patients.

135 We extracted demographic data (including age, sex, location of residence, and insurance

136 type), disease duration, clinical symptoms, biochemical status (at diagnosis and on follow-up),

137 radiographic features, treatment history, histopathology, postoperative complications, and

138 follow-up at 3 months after treatment. Approval (approved ID [2020] 091) for this retrospective 
medRxiv preprint doi: https://doi.org/10.1101/2020.06.26.20141325; this version posted July 27, 2020. The copyright holder for this preprint (which was not certified by peer review) is the author/funder, who has granted medRxiv a license to display the preprint in perpetuity. It is made available under a CC-BY-NC-ND 4.0 International license .

139 study was obtained from CAPA and the institutional review board of The First Affiliated

140 Hospital of Sun Yat-sen University, Guangzhou, China.

\section{Variables Analyzed}

All patients in the CAPA database were diagnosed with acromegaly in accordance with

145 established guidelines (Box 1). ${ }^{8}$ Diagnostic factors include classic signs and symptoms,

146 biochemical assays, and radiographic identification of a pituitary tumor.

\section{Box 1 | Diagnostic and biochemical remission criteria for acromegaly}

\section{Diagnostic criteria}

- Classic signs and symptoms of acromegaly

- Endocrinological assay: fasting growth hormone $(\mathrm{GH})>2.5 \mu \mathrm{g} / \mathrm{L}$, glucose $\mathrm{GH}$ inhibition test with lowest $\mathrm{GH}>1 \mu \mathrm{g} / \mathrm{L}$, and insulin-like growth factor 1 (IGF-1) level higher than the normal range of age- and sex-matched healthy individuals

- Radiographic identification of a pituitary tumor on computed tomography (CT), highresolution magnetic resonance imaging (MRI), or dynamic contrast-enhanced MRI of the sellar region

- Pituitary hormone aberrancies: abnormal levels in prolactin (PRL), follicle stimulating hormone $(\mathrm{FSH})$, luteinizing hormone $(\mathrm{LH})$, thyroid-stimulating hormone (TSH), and/or adrenocorticotropic hormone $(\mathrm{ACTH})$

\section{Biochemical remission criteria $^{8}$}

- Random serum $\mathrm{GH}<2.5 \mu \mathrm{g} / \mathrm{L}$, glucose $\mathrm{GH}$ inhibition test with $\mathrm{GH}<1 \mu \mathrm{g} / \mathrm{L}$

- Normalized serum IGF-1 level

148 Radiographic features

149 Imaging was reviewed by either an attending neurosurgeon or neuroradiologist.

150 Cavernous sinus invasion was classified using the Knosp Grading System. ${ }^{9}$ Tumor invasion was

151 defined as Knosp grades $3 \& 4$ (evidence of tumor crossing the lateral border of the cavernous 
medRxiv preprint doi: https://doi.org/10.1101/2020.06.26.20141325; this version posted July 27, 2020. The copyright holder for this preprint (which was not certified by peer review) is the author/funder, who has granted medRxiv a license to display the preprint in perpetuity.

It is made available under a CC-BY-NC-ND 4.0 International license .

152 carotid artery on coronal MRI image), while lack of invasion was defined as a Knosp score of 0

153 to 2 (margin of tumor medial to the lateral border of cavernous carotid artery). ${ }^{9,10}$

154 Tumor size was classified into three categories: microadenomas (maximum diameter $<1$

$155 \mathrm{~cm})$, macroadenomas $(1-4 \mathrm{~cm})$, and giant adenomas $(\geq 4 \mathrm{~cm}) .^{11}$

157 Location of residence

158 The geographic grouping was performed based on the Yicai Media Group

159 (https://www.yicai.com) stratification of Chinese cities and towns into 5 tiers, which we adapted

160 to classify patient residence into the following categories based on population density and size of

161 economy: large city, medium city, and small city/town.

162

\section{Insurance coverage}

There are three insurance schemes in China, including the urban employee-based basic

165 medical insurance scheme (UEBMI; launched in 1998), urban resident-based basic medical

166 insurance scheme (URBMI; launched in 2007), and rural new cooperative medical scheme

167 (NCMS; launched in 2003), which is intended to provide affordable health insurance for the poor

168 and improve the equity of health services in rural China. ${ }^{12}$ In general, UEBMI covers a broader

169 array of medical services than URBMI, with NCMS having the least robust coverage.

\section{Treatment}

Primary treatment modalities included medication, radiotherapy, or surgery, which

173 comprised of microscopic endonasal, endoscopic endonasal, or transcranial surgery (Figure 1). 
medRxiv preprint doi: https://doi.org/10.1101/2020.06.26.20141325; this version posted July 27, 2020. The copyright holder for this preprint (which was not certified by peer review) is the author/funder, who has granted medRxiv a license to display the preprint in perpetuity.

It is made available under a CC-BY-NC-ND 4.0 International license .

174 The receipt of preoperative medication was decided by an agreement between the physicians and

175 the patients, according to the established guidelines for acromegaly management ${ }^{3,8}$ and the

176 coverage of their medical insurance or financial capacity. All surgical specimens were analyzed

177 using immunohistopathology. Patients who did not achieve initial biochemical remission

178 received one of the following secondary treatments: repeat surgery, radiotherapy, medication, or

179 combined-therapy.

180

181 Outcome Measures

182

The primary outcome of interest was biochemical remission at 3 months postoperatively.

184 The recurrence rate was also identified using the latest follow up information. The criteria for 185 postoperative biochemical remission after surgery for acromegaly were based on the established 186 guidelines $(\mathbf{B o x} \mathbf{1})^{8}$

\section{Statistical Analysis}

Baseline characteristics were described using mean \pm standard deviation (SD), median

191 (interquartile range, IQR), or frequency according to the variable type. Group differences were

192 compared using the two-sample Student's t-test or Mann-Whitney U-test for continuous

193 variables, and Pearson's chi-squared test (two-tailed) or Fisher's exact test for categorical

194 variables, as appropriate. The family discovery rate (FDR) correction was performed across all

195 univariate analyses to adjust for multiple testing. A purposeful selection approach to multivariate

196 logistic regression analysis was performed to determine the independent predictors of 
medRxiv preprint doi: https://doi.org/10.1101/2020.06.26.20141325; this version posted July 27, 2020. The copyright holder for this preprint (which was not certified by peer review) is the author/funder, who has granted medRxiv a license to display the preprint in perpetuity.

It is made available under a CC-BY-NC-ND 4.0 International license .

197 biochemical remission at 3 months postoperatively in patients with acromegaly. Results were

198 presented as odds ratios (ORs) with 95\% confidence intervals (CI). The collinearity between

199 variables was explored and evaluated by the variance influence factor (VIF) in the regression

200 analysis. Significance was set at $p<0.05$ (two-tailed). All statistical analyses were performed

201 using statistical packages in R (https://www.R-project.org/). ${ }^{13}$

203 Results

204 Cohort

205

We retrospectively analyzed presenting features, imaging, and clinical outcomes for 575

207 acromegaly patients (mean age 37.3 110.3 years; 59\% women) from the multi-institutional

208 patient-reported CAPA database. The median time from symptom onset to diagnosis was 5 years

209 (range: 1-10 years). The most common clinical symptoms and signs at presentation were

210 enlarged nose and prognathism (97.4\%) (Table 1). Visual field abnormalities, resulting from

211 tumor mass effect, occurred in $49.2 \%$ of patients. Apoplexy occurred in $9.6 \%$, producing tumor

212 mass effect. Other comorbidities associated with acromegaly were reported as follows:

213 cardiovascular disease (40.0\%), impaired glucose tolerance (31.0\%), osteoporosis $(22.6 \%)$,

214 colonic polyps (16.3\%), arthritis $(15.8 \%)$, and colon cancer $(0.7 \%)$.

215 Large and giant tumors dominated this cohort, with $73.2 \%$ being macroadenomas, $10.1 \%$

216 being giant adenomas, and $16.7 \%$ being microadenomas (Table 2, Figure 2A). Consistent with

217 the prevalence of large tumors in this cohort, two-thirds of the tumors demonstrated cavernous

218 sinus invasion (Table 2, Figure 2A). 
medRxiv preprint doi: https://doi.org/10.1101/2020.06.26.20141325; this version posted July 27, 2020. The copyright holder for this preprint (which was not certified by peer review) is the author/funder, who has granted medRxiv a license to display the preprint in perpetuity.

It is made available under a CC-BY-NC-ND 4.0 International license .

The majority of patients lived in large cities (43.8\%), while only $20.4 \%$ of acromegaly

220 patients were from small cities/towns. The urban employer-driven UEBMI scheme was the most

221 prevalent insurance coverage in our cohort (63.7\%), followed by the urban resident NCMS

$222(22.6 \%)$ and the rural URBMI (13.7\%) plans (Table 1).

223 Median follow-up after the initial diagnosis was 54 months (range 6-295 months), while

224 median follow-up after initial treatment was 32 months (range 3-256 months), suggesting an

225 average of 19 months interval delay between diagnosis and treatment.

227 Endocrinological Status

Among 575 acromegaly patients, the mean levels of GH and IGF-1 prior to surgery were

$230 \quad 26.8 \mu \mathrm{g} / \mathrm{L}$ and $781.5 \mu \mathrm{g} / \mathrm{L}$ respectively. Mean preoperative $\mathrm{GH}$ level was significantly higher in

231 patients with macroadenomas $(27.3 \mu \mathrm{g} / \mathrm{L})$ and giant adenomas $(36.8 \mu \mathrm{g} / \mathrm{L})$ compared to those

232 with microadenomas $(18.5 \mu \mathrm{g} / \mathrm{L}$ ) (both $\mathrm{p}<0.001)$ (Figure 2B). Additionally, tumors with

233 cavernous sinus invasion exhibited significantly higher median GH levels than those without

234 invasion $(28.7 \mu \mathrm{g} / \mathrm{L}$ vs. $23.3 \mu \mathrm{g} / \mathrm{L}, \mathrm{p}<0.001)$ (Figure 2C). Tumors with plurihormonal expression

235 showed higher median GH levels $(22.7 \mu \mathrm{g} / \mathrm{L})$ than dual-staining pituitary tumors of $\mathrm{GH}$ and

236 prolactin (DSPTs) $(20.0 \mu \mathrm{g} / \mathrm{L})$ and $\mathrm{GH}$ alone $(16.5 \mu \mathrm{g} / \mathrm{L})$, but these differences did not reach a

237 statistical significance.

238 
medRxiv preprint doi: https://doi.org/10.1101/2020.06.26.20141325; this version posted July 27, 2020. The copyright holder for this preprint (which was not certified by peer review) is the author/funder, who has granted medRxiv a license to display the preprint in perpetuity.

It is made available under a CC-BY-NC-ND 4.0 International license .

546 patients $(95 \%)$ received surgery as their initial treatment, while 21 patients $(3.7 \%)$

242 received medical therapy alone and 8 patients $(1.3 \%)$ received upfront radiation (Figure 1). The

243 most common operative approach was endoscopic endonasal transsphenoidal (94.9\%), with

244 transcranial surgery (5.1\% of cases) mostly reserved for larger tumors with a greater extent of

245 invasiveness. The mean age of patients who received either medication or radiation only was 49

246 years (range 32-70 years), compared to a mean of 37 years (range 16-76 years) in patients who

247 underwent surgery $(\mathrm{p}<0.001)$. For patients receiving medication alone, mean GH levels trended

248 lower than that of patients who underwent surgery (19.7 vs. $27.0 \mu \mathrm{g} / \mathrm{L}$, respectively; $\mathrm{p}=0.036$ ).

250 Surgical Outcome

Among the 546 patients who underwent initial surgical resection, histopathology confirmed immunopositivity for $\mathrm{GH}$ alone in $81.5 \%$, concurrent $\mathrm{GH}$ and prolactin staining in $25413.7 \%$, and the presence of additional hormone expression along with $\mathrm{GH}$ in the remaining

255 (4.8\%) (Table 2). Tumors that stained for both GH and prolactin were more likely than solely 256 GH-staining tumors to be invasive $(78.7 \%$ vs. $61.1 \%$, respectively; $\mathrm{p}=0.003) .{ }^{14}$ Moreover, the

257 most common postoperative complication was postoperative hyponatremia (sodium <135 $258 \mathrm{mmol} / \mathrm{L})(26.0 \%)$, followed by diabetes insipidus (18.5\%), cerebrospinal fluid leak (6.8\%), 259 meningitis (0.4\%). One case of internal carotid artery (ICA) injury was reported.

260 At three months after surgery, 209 (38.3\%) patients had achieved biochemical remission

261 (Table 3, Figure 1). More aggressive tumors were associated with a lower likelihood of 262 remission at 3 months. Specifically, higher pre-operative GH levels, larger tumors, and the 263 presence of cavernous sinus invasion were all significantly associated with lack of remission 
medRxiv preprint doi: https://doi.org/10.1101/2020.06.26.20141325; this version posted July 27, 2020. The copyright holder for this preprint (which was not certified by peer review) is the author/funder, who has granted medRxiv a license to display the preprint in perpetuity.

It is made available under a CC-BY-NC-ND 4.0 International license .

$264(\mathrm{p}=0.003, \mathrm{p}<0.001, \mathrm{p}<0.001$, respectively). Although biochemical remission was observed in

$26563.6 \%$ of microadenoma patients, it was only observed in $12.3 \%$ of patients with giant adenomas.

266 Similarly, $57.1 \%$ of cases with Knosp grade 0-2 experienced remission, compared to only $27.7 \%$

267 of Knosp grade 3-4 tumors.

268 Multivariate logistic regression analysis showed that preoperative GH levels $>28 \mu \mathrm{g} / \mathrm{L}$

269 (highest tertile of our cohort) compared to pre-operative GH level $<12 \mu \mathrm{g} / \mathrm{L}$ (lowest tertile in our

270 cohort) decreased the odds of remission at 3 months after surgery by $44 \%$ ( $\mathrm{p}=0.016$ ), adjusted for

271 tumor size and receipt of preoperative medication. Additionally, having a macroadenoma or

272 giant adenoma decreased the odds of remission by $43 \%(\mathrm{p}=0.041)$ and $83 \%(\mathrm{p}=0.0005)$,

273 respectively, compared to having a microadenoma. Similarly, tumors with a Knosp score of 3-4

274 had $61 \%$ less odds of biochemical remission at 3 months than those with a Knosp score of 0-2

275 ( $\mathrm{p}<0.0001)$. Adjusted for age, preoperative GH level, tumor size, and Knosp score, preoperative

276 medication usage more than doubled the odds of biochemical remission $(\mathrm{OR}=2.16, \mathrm{p}=0.0008)$

277 (Figure 3). The reduction of statistical power through a high correlation between two or more

278 explanatory variables (multicollinearity) was not observed in our regression model (maximum

$279 \quad \mathrm{VIF}=1.3)$.

280 The recurrence rate was lower in patients with initial biochemical remission $(45.0 \%)$

281 compared to patients without initial remission (65.9\%) who presented lowest recurrent rate in

282 repeat surgery (48.6\%) compared to patients undergoing radiotherapy (59.6\%), medication

$283(63.2 \%)$, and combined treatments (75.6\%) (Figure 1).

284 Patient age, sex, disease duration, city type of residence, insurance type, apoplexy,

285 surgical approach (microscopic endonasal, endoscopic endonasal, or transcranial), and 
medRxiv preprint doi: https://doi.org/10.1101/2020.06.26.20141325; this version posted July 27, 2020. The copyright holder for this preprint (which was not certified by peer review) is the author/funder, who has granted medRxiv a license to display the preprint in perpetuity.

It is made available under a CC-BY-NC-ND 4.0 International license .

286 plurihormonal expression were not significantly associated with postoperative biochemical

287 remission in this cohort.

\section{Discussion}

We present the clinical characteristics of over 500 acromegaly patients in China and

291 observe tumor and treatment factors strongly associated with disease control at three months 292 after surgery or other definitive treatment. Our study represents the largest analysis of clinical

293 features and postoperative outcomes of acromegaly in China, and also constitutes the first

294 application of the CAPA database for clinical research. We observed a 3-month postoperative 295 remission rate of $38.3 \%$, with the likelihood of disease control strongly influenced by the 296 preoperative GH level, tumor size, and tumor invasiveness as indicated by the Knosp grade.

298 particularly in English-language journals. The earliest record of a surgical case of acromegaly in 299 China dates back to 1929 , when the first patient was operated on using transcranial surgery at the

300 Peking Union Medical College Hospital (records endure in archives of the hospital library).

301 Early published studies from China were mostly case series and smaller cohorts. More recently, a

302 single-institution retrospective analysis of 358 Chinese acromegalic patients found the GH 303 remission rate to be $37.3 \%$ in patients with invasive macroadenomas without receipt of 304 preoperative somatostatin analogs as compared to $56.4 \%$ among those with pre-operative 305 medical treatment. ${ }^{15}$ We drew upon the power of a patient-reported database to expand on the 306 clinical experience in the diagnosis and treatment of acromegaly in China across multiple 307 institutions. 
medRxiv preprint doi: https://doi.org/10.1101/2020.06.26.20141325; this version posted July 27, 2020. The copyright holder for this preprint (which was not certified by peer review) is the author/funder, who has granted medRxiv a license to display the preprint in perpetuity.

It is made available under a CC-BY-NC-ND 4.0 International license .

\section{Clinical characteristics}

Although the most commonly reported physical changes in our cohort were similar to

312 previously published series, ${ }^{2,16}$ the detection of such changes may occur in a delayed fashion

313 given the typically insidious onset over decades. Additionally, dental malocclusion, median

314 thenar neuropathy (carpal tunnel syndrome), change in shoe size or ring size, and skin tags may

315 be overlooked signs of acromegaly. Sleep apnea, headache, and hyperhidrosis were observed in

316 over half of patients, in addition to menstrual disturbances in two-thirds of female patients.

317 These, among other common non-physical, symptoms should prompt closer inspection for

318 physical signs of acromegaly and consideration for endocrinological evaluation, including

319 assaying IGF-1 determinations.

320 Although visual field deficit clearly triggers an alarm for a compressive etiology

321 involving the optic apparatus, $52.5 \%$ of patients with macroadenomas did not report any

322 subjective visual impairment. Clinical concern for a large pituitary tumor, as in aggressive

323 acromegaly cases, should prompt formal neuro-ophthalmologic evaluation.

324 Acromegaly is associated with premature mortality. ${ }^{17,18}$ Older age at diagnosis, increased

325 time from symptom onset to diagnosis, higher GH levels after treatment, and cardiovascular risk

326 factors are independent predictors of early mortality. ${ }^{18}$ Forty percent of patients in this cohort

327 reported cardiovascular symptoms or disease, including heart palpitations, arrhythmias (e.g.,

328 atrial fibrillation and heart block), structural heart diseases (e.g., cardiomyopathy and valvular

329 disease), and hypertension. These findings, when viewed in light of the fact that the mean age of

330 our cohort was only 37.3 years, underscores the strikingly significant impact of acromegaly on

331 cardiovascular health. ${ }^{19}$ Furthermore, the high incidence of impaired glucose tolerance (diabetes 
medRxiv preprint doi: https://doi.org/10.1101/2020.06.26.20141325; this version posted July 27, 2020. The copyright holder for this preprint (which was not certified by peer review) is the author/funder, who has granted medRxiv a license to display the preprint in perpetuity.

It is made available under a CC-BY-NC-ND 4.0 International license .

332 mellitus), osteoporosis, colonic polyps, and arthritis/arthropathies observed also supports the

333 need for diligent and careful screening by providers, as outlined by the Endocrine Society

334 Clinical Practice Guidelines for acromegaly. ${ }^{1}$ Early diagnosis in conjunction with effective

335 treatment and persistent control/screening of comorbidities are paramount to decreasing the

336 morbidity and mortality associated with this condition.

Factors influencing biochemical remission

The $38.3 \%$ biochemical remission rate at 3-months after surgery for a GH secreting

341 tumor in our cohort is relatively low compared to other reports in the literature. ${ }^{20,21}$ This may

342 reflect the high proportion of large and invasive tumors encompassed by our cohort. Additionally,

343 cultural factors and health literacy for neuroendocrinological diseases may contribute to a delay

344 in seeking medical care, resulting in the disease progression. In addition, 1 in 5 patients in our

345 cohort was from a small city or town, which may further delay access to medical care and

346 endocrinological evaluation. Although we did not observe a statistically significant impact of

347 socioeconomic or insurance status on the likelihood of biochemical remission after surgery for

348 acromegaly in this patient-reported cohort, further investigations are merited to improve the

349 delay between diagnosis and treatment, and also potential delays in the initial recognition of

350 acromegaly, especially amongst individuals with geographical and financial barriers.

351 Preoperative clinical and biochemical characteristics could impact the likelihood of

352 biochemical remission, including age at diagnosis, ${ }^{22}$ gender, ${ }^{22}$ preoperative serum levels of $\mathrm{GH}$

353 and IGF-1,,$^{20,23-27}$ tumor size $^{20,24,28,29}$ preoperative medication usage, ${ }^{15,21}$ tumor

354 invasiveness, ${ }^{20,24,27-31}$ and histological pathology. ${ }^{24,30}$ Similar to other studies, our analysis also 
medRxiv preprint doi: https://doi.org/10.1101/2020.06.26.20141325; this version posted July 27, 2020. The copyright holder for this preprint (which was not certified by peer review) is the author/funder, who has granted medRxiv a license to display the preprint in perpetuity.

It is made available under a CC-BY-NC-ND 4.0 International license .

355 revealed that larger tumors (giant and macroadenomas) were less likely than small tumors to

356 enter biochemical remission at 3 months. Further, patients with invasive tumors and higher

357 preoperative GH levels were less likely to attain remission, adjusted for tumor size and receipt of

358 preoperative medical therapy. Given that aggressive tumors were shown to be less likely to enter

359 biochemical remission postoperatively, early surgical intervention should be instituted to halt

360 further progression of disease. ${ }^{32}$

361 Pharmaceutical treatment, including somatostatin receptor ligands (SRLs), growth

362 hormone receptor antagonists, and dopamine agonists (DA), have shown to have a beneficial

363 impact on surgical outcomes as both neoadjuvant and adjuvant therapy, ${ }^{15,21}$ which was also

364 demonstrated by our team. ${ }^{33}$ In particular, administration of somatostatin analogs prior to surgery

365 is associated with higher endocrinological remission than adjuvant treatment alone. ${ }^{15,34-37}$

366 Likewise, the use of preoperative medical treatment more than doubled the odds of remission in

367 our cohort.

368 Long-term remission in patients with initial remission showed a delayed improvement of

369 biochemical remission. Among secondary treatments in patients without initial remission, the

370 lowest recurrence rate presented in patients undergoing repeat surgery, the necessity of which is

371 highlighted in persistent cases with invasive tumors. ${ }^{38,39}$

372

373 Limitations

374 Our study strengthens the insight into the patterns of care and results of treatment for

375 acromegaly in China. The vast heterogeneity in the regional economy, insurance coverage,

376 education, health literacy, and accessibility of medical care, however, may limit the

377 generalizability of these results to all acromegaly patients in China. The self-reported nature of 
medRxiv preprint doi: https://doi.org/10.1101/2020.06.26.20141325; this version posted July 27, 2020. The copyright holder for this preprint (which was not certified by peer review) is the author/funder, who has granted medRxiv a license to display the preprint in perpetuity.

It is made available under a CC-BY-NC-ND 4.0 International license .

378 the CAPA database further contributed to a significant burden of missing data at extent of

379 resection, detailed pathological results (Ki-67, somatostatin receptor subtype 2 expression, AIP

380 expression, and granularity), dates of secondary treatment, and continuous follow-ups. Although

381 we have the last follow-up record, which might underestimate the time to recurrence and

382 therefore limit us to further investigate predictors of long-term outcomes. Finally, as evidenced

383 by the low median age of our cohort, the majority of patients who contributed to this database

384 through online submission were young, likely reflecting age-related biases in adopting an

385 electronic reporting platform. Strategies to expand access and ease of data accrual from more

386 diverse populations, both in demographics and age, may further diversify the value of this

387 clinical database in the future.

\section{Conclusions}

We present the largest nation-wide analysis of clinical features and surgical outcomes of

391 acromegaly patients in China, driven from a patient-reported database. We highlight that higher

392 preoperative GH levels, giant adenomas, and greater extent of tumor invasiveness are associated

393 with a lower likelihood of biochemical remission at 3-months after surgery, while preoperative

394 medical therapy increases the chance of remission. Importantly, we have established the

395 effectiveness and potential of a patient-reported database in advancing neuroendocrinological

396 research. 
medRxiv preprint doi: https://doi.org/10.1101/2020.06.26.20141325; this version posted July 27, 2020. The copyright holder for this preprint (which was not certified by peer review) is the author/funder, who has granted medRxiv a license to display the preprint in perpetuity.

It is made available under a CC-BY-NC-ND 4.0 International license .

401 The authors report no conflict of interest concerning the materials or methods used in this study

402 or the findings specified in this paper.

403

\section{Acknowledgments}

405 The authors would like to thank all the patients and families and their providers who collaborated

406 with the establishment of CAPA database. We are grateful for the collaboration with the Chinese

407 Association of Patients with Acromegaly (CAPA). We also thank Mr. Hao Luo (Warwick

408 Business School, United Kingdom) for creating the China heat-map for the geographic

409 distribution of acromegaly patients.

\section{Author Contributions}

412 Conception and design: WL Chen, HJ Wang, and WL Bi. Acquisition of data: WL Chen and HJ

413 Wang. Analysis and Interpretation of data: all authors. Drafting the article: S Yao, S Tavakol, 414 and WL Bi. Critically revising the article: S Yao, S Tavakol, F Akter, MP Catalino, ER Laws,

415 WL Bi, and HJ Wang. Reviewed submitted version of manuscript: all authors. Approved the 416 final version of manuscript on behalf of all authors: HJ Wang. Statistical analysis: S Yao, S 417 Tavakol, WL Bi. Graphic visualization: S Yao. Clinical diagnosis and radiological identification: 418 WL Chen, J Luo, and ZG Mao. Administrative/technical/material support: WL Chen, ZG Mao, 419 YH Zhu, and HJ Wang. Study supervision: HJ Wang and WL Bi. 


\section{References:}

422 1. Katznelson L, Laws ER, Melmed S, et al. Acromegaly: An Endocrine Society Clinical

423 Practice Guideline. J Clin Endocrinol Metab. 2014;99(11):3933-3951. doi:10.1210/jc.2014-

$424 \quad 2700$

2. Colao A, Grasso LFS, Giustina A, et al. Acromegaly. Nat Rev Dis Primers. 2019;5(1):20. doi:10.1038/s41572-019-0071-6

3. Cook DM, Ezzat S, Katznelson L, et al. AACE Medical Guidelines for Clinical Practice for the diagnosis and treatment of acromegaly. Endocr Pract. 2004;10(3):213-225. doi:10.4158/EP.10.3.213

4. Abreu A, Tovar AP, Castellanos R, et al. Challenges in the diagnosis and management of acromegaly: a focus on comorbidities. Pituitary. 2016;19:448-457. doi:10.1007/s11102-

5. Melmed S. Acromegaly. New England Journal of Medicine. 2006;355(24):2558-2573. doi:10.1056/NEJMra062453 016-0725-2 
medRxiv preprint doi: https://doi.org/10.1101/2020.06.26.20141325; this version posted July 27, 2020. The copyright holder for this preprint (which was not certified by peer review) is the author/funder, who has granted medRxiv a license to display the preprint in perpetuity. It is made available under a CC-BY-NC-ND 4.0 International license .

8. Chinese Society of Endocrinology, Chinese Neurosurgical Society, and Chinese Pituitary

9. Knosp E, Steiner E, Kitz K, Matula C. Pituitary adenomas with invasion of the cavernous (2013). Natl Med J China. 2013;93(27):2106-2111. doi:10.3760/cma.j.issn.0376-

10. Mooney MA, Hardesty DA, Sheehy JP, et al. Interrater and intrarater reliability of the Knosp scale for pituitary adenoma grading. Journal of Neurosurgery. 2017;126(5):1714-1719.

11. Molitch ME. Diagnosis and Treatment of Pituitary Adenomas: A Review. JAMA.

12. Meng Q, Fang H, Liu X, Yuan B, Xu J. Consolidating the social health insurance schemes in doi:10.3171/2016.3.JNS153044 2017;317(5):516-524. doi:10.1001/jama.2016.19699 causing acromegaly: a retrospective review of clinical presentations and surgical outcomes. 
medRxiv preprint doi: https://doi.org/10.1101/2020.06.26.20141325; this version posted July 27, 2020. The copyright holder for this preprint (which was not certified by peer review) is the author/funder, who has granted medRxiv a license to display the preprint in perpetuity. It is made available under a CC-BY-NC-ND 4.0 International license .

459 15. Duan L, Zhu H, Xing B, Gu F. Prolonged preoperative treatment of acromegaly with

460 Somatostatin analogs may improve surgical outcome in patients with invasive pituitary

461 macroadenoma (Knosp grades 1-3): a retrospective cohort study conducted at a single

462 center. BMC Endocr Disord. 2017;17(1):55. doi:10.1186/s12902-017-0205-3

463 16. Hoskuldsdottir GT, Fjalldal SB, Sigurjonsdottir HA. The incidence and prevalence of

464 acromegaly, a nationwide study from 1955 through 2013. Pituitary. 2015;18(6):803-807.

465 doi:10.1007/s11102-015-0655-4

17. Dekkers OM, Biermasz NR, Pereira AM, Romijn JA, Vandenbroucke JP. Mortality in Acromegaly: A Metaanalysis. J Clin Endocrinol Metab. 2008;93(1):61-67. doi:10.1210/jc.2007-1191

18. Holdaway IM, Rajasoorya RC, Gamble GD. Factors Influencing Mortality in Acromegaly. $J$ Clin Endocrinol Metab. 2004;89(2):667-674. doi:10.1210/jc.2003-031199

19. Guo X, Gao L, Zhang S, et al. Cardiovascular System Changes and Related Risk Factors in Acromegaly Patients: A Case-Control Study. Int J Endocrinol. 2015;2015:573643. doi:10.1155/2015/573643 
medRxiv preprint doi: https://doi.org/10.1101/2020.06.26.20141325; this version posted July 27, 2020. The copyright holder for this preprint (which was not certified by peer review) is the author/funder, who has granted medRxiv a license to display the preprint in perpetuity.

It is made available under a CC-BY-NC-ND 4.0 International license .

477

478

479

480

481

482

483

484

485

486

487

488

489

490

491

492

493

21. Yang C, Li G, Jiang S, Bao X, Wang R. Preoperative Somatostatin Analogues in Patients with Newly-diagnosed Acromegaly: A Systematic Review and Meta-analysis of Comparative Studies. Sci Rep. 2019;9(1):1-9. doi:10.1038/s41598-019-50639-6

22. Park SH, Ku CR, Moon JH, Kim EH, Kim SH, Lee EJ. Age- and Sex-Specific Differences as Predictors of Surgical Remission Among Patients With Acromegaly. J Clin Endocrinol Metab. 2018;103(3):909-916. doi:10.1210/jc.2017-01844

23. Minniti G, Jaffrain-Rea M-L, Esposito V, Santoro A, Tamburrano G, Cantore G. Evolving criteria for post-operative biochemical remission of acromegaly: can we achieve a definitive cure? An audit of surgical results on a large series and a review of the literature. Endocr Relat Cancer. 2003;10(4):611-619. doi:10.1677/erc.0.0100611

24. Fernandez-Rodriguez E, Casanueva FF, Bernabeu I. Update on prognostic factors in acromegaly: Is a risk score possible? Pituitary. 2015;18(3):431-440. doi:10.1007/s11102014-0574-9

25. Kaltsas GA, Isidori AM, Florakis D, et al. Predictors of the outcome of surgical treatment in acromegaly and the value of the mean growth hormone day curve in assessing postoperative disease activity. J Clin Endocrinol Metab. 2001;86(4):1645-1652. doi:10.1210/jcem.86.4.7398

26. Biermasz NR, Dekker FW, Pereira AM, et al. Determinants of Survival in Treated Acromegaly in a Single Center: Predictive Value of Serial Insulin-Like Growth Factor I Measurements. J Clin Endocrinol Metab. 2004;89(6):2789-2796. doi:10.1210/jc.2003032041 
medRxiv preprint doi: https://doi.org/10.1101/2020.06.26.20141325; this version posted July 27, 2020. The copyright holder for this preprint (which was not certified by peer review) is the author/funder, who has granted medRxiv a license to display the preprint in perpetuity. It is made available under a CC-BY-NC-ND 4.0 International license .

27. Tindall GT, Oyesiku NM, Watts NB, Clark RV, Christy JH, Adams DA. Transsphenoidal adenomectomy for growth hormone-secreting pituitary adenomas in acromegaly: outcome analysis and determinants of failure. J Neurosurg. 1993;78(2):205-215. doi:10.3171/jns.1993.78.2.0205

28. Sun H, Brzana J, Yedinak CG, Gultekin SH, Delashaw JB, Fleseriu M. Factors Associated with Biochemical Remission after Microscopic Transsphenoidal Surgery for Acromegaly. $J$ Neurol Surg B. 2014;75(1):47-52. doi:10.1055/s-0033-1354578

29. Laws ER, Piepgras DG, Randall RV, Abboud CF. Neurosurgical management of acromegaly. Results in 82 patients treated between 1972 and 1977. J Neurosurg. 1979;50(4):454-461. doi:10.3171/jns.1979.50.4.0454

30. Nomikos P, Buchfelder M, Fahlbusch R. The outcome of surgery in 668 patients with acromegaly using current criteria of biochemical 'cure.' European Journal of Endocrinology. 2005;152(3):379-387. doi:10.1530/eje.1.01863

31. Antunes X, Ventura N, Camilo GB, et al. Predictors of surgical outcome and early criteria of remission in acromegaly. Endocrine. 2018;60(3):415-422. doi:10.1007/s12020-018-1590-8

32. Laws ER. Surgery for acromegaly: evolution of the techniques and outcomes. Rev Endocr Metab Disord. 2008;9(1):67-70. doi:10.1007/s11154-007-9064-y

33. Mao Z, Zhu Y, Tang H, et al. Preoperative lanreotide treatment in acromegalic patients with macroadenomas increases short-term postoperative cure rates: a prospective, randomised trial. European Journal of Endocrinology. 2010;162(4):661-666. doi:10.1530/EJE-09-0908 
medRxiv preprint doi: https://doi.org/10.1101/2020.06.26.20141325; this version posted July 27, 2020. The copyright holder for this preprint (which was not certified by peer review) is the author/funder, who has granted medRxiv a license to display the preprint in perpetuity.

It is made available under a CC-BY-NC-ND 4.0 International license . somatostatin analogues versus direct transsphenoidal surgery for newly-diagnosed acromegaly patients: a systematic review and meta-analysis using the GRADE system.

35. Albarel F, Castinetti F, Morange I, et al. Pre-surgical medical treatment, a major prognostic

$$
\text { Pituitary. 2015;18(4):500-508. doi:10.1007/s11102-014-0602-9 }
$$

36. Shen M, Shou X, Wang Y, et al. Effect of presurgical long-acting octreotide treatment in acromegaly patients with invasive pituitary macroadenomas: a prospective randomized study. Endocr J. 2010;57(12):1035-1044. doi:10.1507/endocrj.k10e-203

37. Vance ML, Laws ER. Role of medical therapy in the management of acromegaly.

38. Asha MJ, Takami H, Velasquez C, et al. Long-term outcomes of transsphenoidal surgery for management of growth hormone-secreting adenomas: single-center results. Journal of for the treatment of remaining or recurring pituitary tumors in acromegaly. Neurosurgery. Neurosurgery. Published online October 2019:1-11. doi:10.3171/2019.6.JNS191187 
medRxiv preprint doi: https://doi.org/10.1101/2020.06.26.20141325; this version posted July 27, 2020. The copyright holder for this preprint (which was not certified by peer review) is the author/funder, who has granted medRxiv a license to display the preprint in perpetuity. It is made available under a CC-BY-NC-ND 4.0 International license .

537 Table 1. Demographics and clinical presentation $(\mathrm{N}=575)$

\begin{tabular}{|c|c|}
\hline Categories & Distribution \\
\hline Mean age (years), mean \pm SD & $37.3 \pm 10.3$ \\
\hline Male / Female & $235 / 340$ \\
\hline Disease duration (years), median (IQR) & $5(2.5-8.0)$ \\
\hline Follow-up after initial diagnosis (months), median (IQR) & $54(30-86)$ \\
\hline Follow-up after initial treatment (months), median (IQR) & $32(13-61)$ \\
\hline \multicolumn{2}{|l|}{ Clinical symptoms and signs, $\mathrm{n}(\%)$} \\
\hline Enlarged nose and prognathism & $560(97.4)$ \\
\hline Overgrowth of extremities & $537(93.4)$ \\
\hline Menstrual disturbance (female) & $227(66.8)$ \\
\hline Snoring or sleep apnea & $358(62.3)$ \\
\hline Headache & $336(58.4)$ \\
\hline Hyperhidrosis & $323(56.2)$ \\
\hline Hypertrophy of frontal bones & $287(49.9)$ \\
\hline Visual field abnormalities & $283(49.2)$ \\
\hline Cardiovascular disease & $230(40.0)$ \\
\hline Impaired glucose tolerance & $178(31.0)$ \\
\hline Hypertrichosis & $197(34.3)$ \\
\hline Jaw malocclusion & $139(24.2)$ \\
\hline Osteoporosis & $130(22.6)$ \\
\hline Colonic polyps & $94(16.3)$ \\
\hline Arthritis & $91(15.8)$ \\
\hline Galactorrhea & $88(15.3)$ \\
\hline Colonic cancer & $4(0.7 \%)$ \\
\hline \multicolumn{2}{|l|}{ Resident area } \\
\hline Large city & $252(43.8)$ \\
\hline Medium city & $206(35.8)$ \\
\hline Small city/town & $117(20.4)$ \\
\hline \multicolumn{2}{|l|}{ Insurance type } \\
\hline Urban Employee Basic Medical Insurance & $366(63.7)$ \\
\hline New Cooperative Medical Scheme & $130(22.6)$ \\
\hline Urban Resident Basic Medical Insurance & $79(13.7)$ \\
\hline
\end{tabular}

539 Abbreviations: IQR, interquartile range; SD, standard deviation. 
medRxiv preprint doi: https://doi.org/10.1101/2020.06.26.20141325; this version posted July 27, 2020. The copyright holder for this preprint (which was not certified by peer review) is the author/funder, who has granted medRxiv a license to display the preprint in perpetuity.

It is made available under a CC-BY-NC-ND 4.0 International license .

541 Table 2. Tumor characteristics and treatment $(\mathrm{N}=575)$

542

\begin{tabular}{|c|c|}
\hline Categories & Distribution \\
\hline \multicolumn{2}{|l|}{ Initial biochemical levels } \\
\hline$G H(\mu g / L)$, mean $\pm S D$ & $26.8 \pm 26.1$ \\
\hline$I G F-1(\mu g / L)$, mean $\pm S D$ & $781.5 \pm 290.8$ \\
\hline \multicolumn{2}{|l|}{ 3-month biochemical levels } \\
\hline$G H(\mu g / L)$, median, (IQR) & $4.32(1.3-11.2)$ \\
\hline$I G F-1(\mu g / L)$, mean $\pm S D$ & $572.3 \pm 289.7$ \\
\hline \multicolumn{2}{|l|}{ Tumor size, $\mathrm{n}(\%)$} \\
\hline Microadenomas $(<1 \mathrm{~cm})$ & $96(16.7)$ \\
\hline Macroadenomas (1 - 4cm) & $421(73.2)$ \\
\hline Giant adenomas ( $\geq 4 \mathrm{~cm})$ & $58(10.1)$ \\
\hline \multicolumn{2}{|l|}{ Knosp score, n (\%) } \\
\hline Score 0 & $58(10.1)$ \\
\hline Score 1 & $110(19.1)$ \\
\hline Score 2 & $54(9.4)$ \\
\hline Score 3 & $270(47.0)$ \\
\hline Score 4 & $83(14.4)$ \\
\hline Apoplexy, n (\%) & $55(9.6)$ \\
\hline Preoperative medication, $\mathrm{n}(\%)$ & $125(21.7)$ \\
\hline \multicolumn{2}{|l|}{ Initial treatment, $\mathrm{n}(\%)$} \\
\hline Radiotherapy & $8(1.3)$ \\
\hline Medication & $21(3.7)$ \\
\hline Surgery & $546(95)$ \\
\hline \multicolumn{2}{|l|}{ Pathology, n (\%) } \\
\hline $\mathrm{GH}$ & $445(81.5)$ \\
\hline$G H+P R L$ & $75(13.7)$ \\
\hline$G H+T S H$ & $5(0.9)$ \\
\hline$G H+A C T H$ & $3(0.6)$ \\
\hline $\mathrm{GH}+(>2$ hormones $)$ & $18(3.3)$ \\
\hline \multicolumn{2}{|l|}{ Postoperative complications, $n^{*}(\%)$} \\
\hline Transient hyponatremia & $142(26.0)$ \\
\hline Transient diabetes insipidus & $101(18.5)$ \\
\hline Cerebrospinal fluid leak & $37(6.8)$ \\
\hline Meningitis & $2(0.4)$ \\
\hline ICA injury (intraoperative) & $1(0.2)$ \\
\hline
\end{tabular}


medRxiv preprint doi: https://doi.org/10.1101/2020.06.26.20141325; this version posted July 27, 2020. The copyright holder for this preprint (which was not certified by peer review) is the author/funder, who has granted medRxiv a license to display the preprint in perpetuity. It is made available under a CC-BY-NC-ND 4.0 International license .

543 Abbreviations: ACTH, Adrenocorticotropic hormone; GH, growth hormone; ICA, intracranial artery; 544 IGF-1, insulin-like growth factor 1; IQR, interquartile range; PRL, prolactin; SD, standard deviation; $545 \mathrm{TSH}$, thyroid stimulating hormone. 
medRxiv preprint doi: https://doi.org/10.1101/2020.06.26.20141325; this version posted July 27, 2020. The copyright holder for this preprint (which was not certified by peer review) is the author/funder, who has granted medRxiv a license to display the preprint in perpetuity.

It is made available under a CC-BY-NC-ND 4.0 International license .

Table 3. Comparison of demographics and clinical presentation between 3-month nonremission and remission cases

\begin{tabular}{|c|c|c|c|}
\hline \multirow{2}{*}{ Categories } & \multicolumn{2}{|c|}{ Surgical remission } & \multirow{2}{*}{ P-value } \\
\hline & No $(n=337)$ & Yes $(n=209)$ & \\
\hline Age (years), mean \pm SD & $36.0 \pm 9.7$ & $38.2 \pm 10.1$ & 0.08 \\
\hline Sex & & & 0.966 \\
\hline Male & $137(62.0)$ & $84(38.0)$ & \\
\hline Female & $200(61.5)$ & $125(39.5)$ & \\
\hline Disease duration (years), median (IQR) & $4(2-8)$ & $5(2-8)$ & 0.361 \\
\hline Initial GH levels $(\mu \mathrm{g} / \mathrm{L})$, median (IQR) & $20.0(12.0-40.0)$ & $14.6(10.2-29.9)$ & 0.003 \\
\hline Tumor size, $\mathrm{n}(\%)$ & & & $<0.001$ \\
\hline Microadenomas & $32(36.4)$ & $56(63.6)$ & \\
\hline Macroadenomas & $255(63.6)$ & $146(36.4)$ & \\
\hline Giant adenomas & $50(87.7)$ & $7(12.3)$ & \\
\hline Knosp score, n (\%) & & & $<0.001$ \\
\hline $0-2$ & $84(42.9)$ & $112(57.1)$ & \\
\hline $3-4$ & $253(72.3)$ & $97(27.7)$ & \\
\hline Apoplexy, n (\%) & $31(62.0)$ & $19(38.0)$ & 0.966 \\
\hline Preoperative medication, $\mathrm{n}(\%)$ & $67(53.6)$ & $58(46.4)$ & 0.08 \\
\hline Surgical approach, n (\%) & & & 0.262 \\
\hline Transcranial surgery & $22(78.6)$ & $6(21.4)$ & \\
\hline Microscopic TSS & $131(62.7)$ & $78(37.3)$ & \\
\hline Endoscopic TSS & $184(59.5)$ & $125(40.5)$ & \\
\hline Pathology, n (\%) & & & 0.727 \\
\hline$G H$ & $269(60.5)$ & $176(39.5)$ & \\
\hline$G H+A C T H$ & $2(66.7)$ & $1(33.3)$ & \\
\hline$G H+P R L$ & $49(65.3)$ & $26(34.7)$ & \\
\hline$G H+T S H$ & $3(60.0)$ & $2(40.0)$ & \\
\hline $\mathrm{GH}+$ (> 2 hormones) & $14(77.8)$ & $4(22.2)$ & \\
\hline City type of residence & & & 0.521 \\
\hline Large city & $138(58.7)$ & $97(41.3)$ & \\
\hline Medium city & $131(65.5)$ & $69(34.5)$ & \\
\hline Small city/town & $68(61.3)$ & $43(38.7)$ & \\
\hline Insurance type & & & 0.721 \\
\hline Urban Employee Basic Medical Insurance & $211(61.9)$ & $130(38.1)$ & \\
\hline New Cooperative Medical Scheme & $83(64.3)$ & $46(35.7)$ & \\
\hline Urban Resident Basic Medical Insurance & $43(56.6)$ & $33(43.4)$ & \\
\hline
\end{tabular}

\section{${ }^{\mathrm{d}}$ FDR correction}

Abbreviations: ACTH, Adrenocorticotropic hormone; eTSS, endonasal transsphenoidal surgery; 
medRxiv preprint doi: https://doi.org/10.1101/2020.06.26.20141325; this version posted July 27, 2020. The copyright holder for this preprint (which was not certified by peer review) is the author/funder, who has granted medRxiv a license to display the preprint in perpetuity.

It is made available under a CC-BY-NC-ND 4.0 International license .

552 Table 4. Multivariate predictors of 3-month surgical remission in acromegaly patients

\begin{tabular}{|c|c|c|c|}
\hline \multirow{2}{*}{ Variable } & \multicolumn{3}{|c|}{ Logistic regression analysis } \\
\hline & OR & $95 \% \mathrm{Cl}$ & $P$ value \\
\hline \multicolumn{4}{|c|}{ Preoperative GH Level $(\mu \mathrm{g} / \mathrm{L})^{a}$} \\
\hline $12-28$ & 0.61 & $0.39-0.96$ & 0.031 \\
\hline$>28$ & 0.56 & $0.35-0.90$ & 0.016 \\
\hline \multicolumn{4}{|l|}{ Tumor size ${ }^{b}$} \\
\hline Macroadenoma & 0.57 & $0.33-0.97$ & 0.041 \\
\hline Giant adenoma & 0.17 & $0.06-0.44$ & 0.0005 \\
\hline Knosp score: $3-4^{c}$ & 0.39 & $0.25-0.59$ & $<0.0001$ \\
\hline $\begin{array}{l}\text { Preoperative medication } \\
\text { usage }\end{array}$ & 2.16 & $1.38-3.39$ & 0.0008 \\
\hline
\end{tabular}

${ }^{a}$ Reference level $<12 \mu \mathrm{g} / \mathrm{L}$

${ }^{\mathrm{b}}$ Reference: Microadenoma

Anosp score 0-2

558 Abbreviations: $\mathrm{Cl}$, confidence interval; $\mathrm{GH}$, growth hormone; OR, odds ratio. 


\section{$559 \quad$ Figure Legends}

560 Figure 1. Treatment pathways among patients in the CAPA cohort.

562 Figure 2. (A) Distribution of cases by Knosp classification and tumor size. (B \& C) The

563 association of preoperative growth hormone $(\mathrm{GH})$ levels compared with tumor size and Knosp

564 score.

565

566 Figure 3. Adjusted odds ratios (OR) and 95\% confidence intervals for predictors of biochemical

567 remission at 3 months $(\mathrm{p}<0.05) .{ }^{\mathrm{a}}$ Reference level: $<12 \mu \mathrm{g} / \mathrm{L} ;{ }^{\mathrm{b}}$ Reference: Microadenoma;

$568{ }^{c}$ Reference: Knosp score 0-2.

572 Supplemental Material S1. The geographic distribution of acromegaly patients in the China

573 Acromegaly Patient Association (CAPA) database between 1998 and 2018, across 23 provinces,

5744 autonomous regions, 4 municipalities, and 2 Special Administrative Regions (Hong Kong and

575 Macau) in China. 


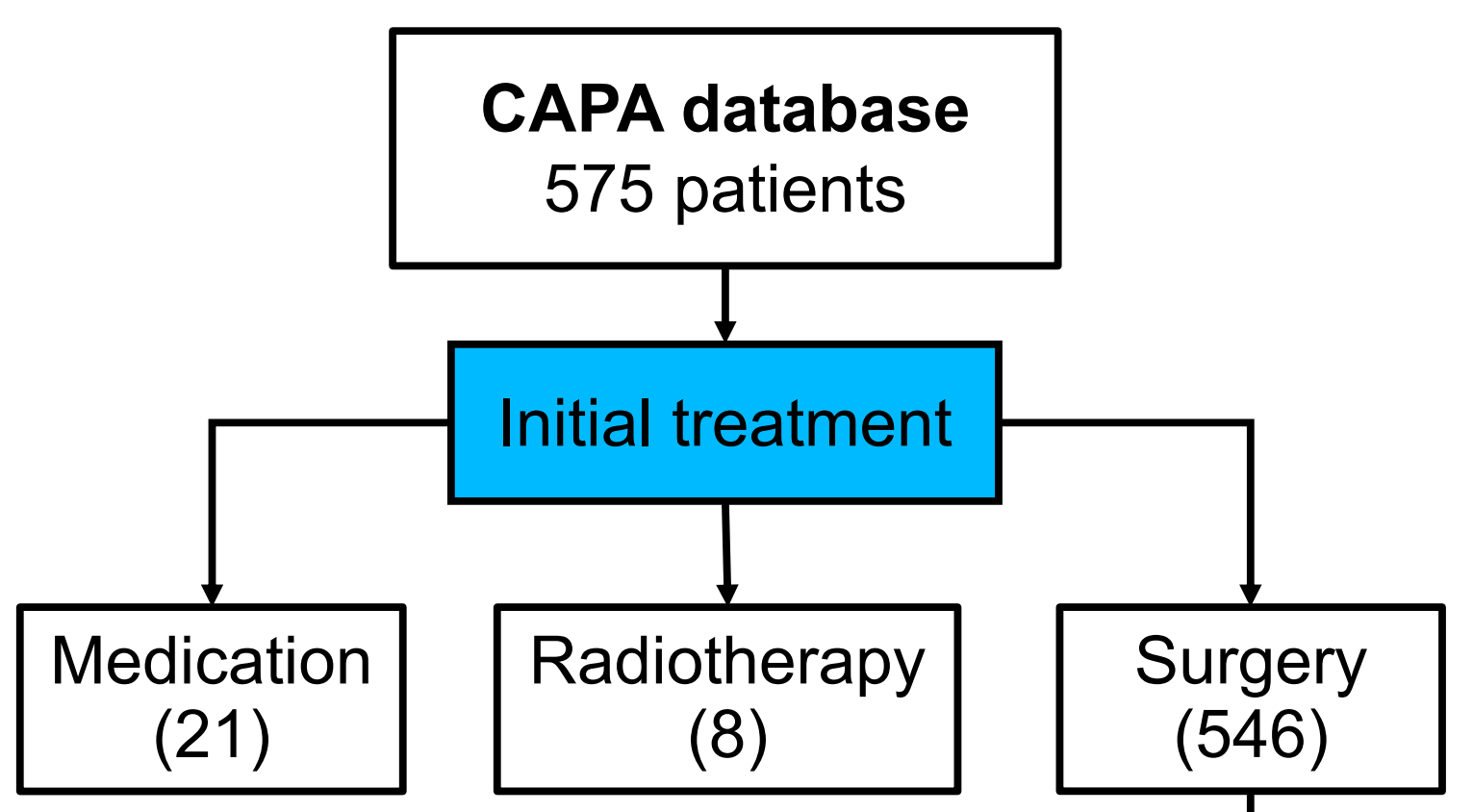

medRxiv preprint doi: https://doi.org/10.1101/2020.06.26.20141325; this version posted July 27, 2020. The copyright holder for this preprint (which was not certified by peer review) is the authorffunder, who has granted medRxiv a license to display the preprint in perpetuity.

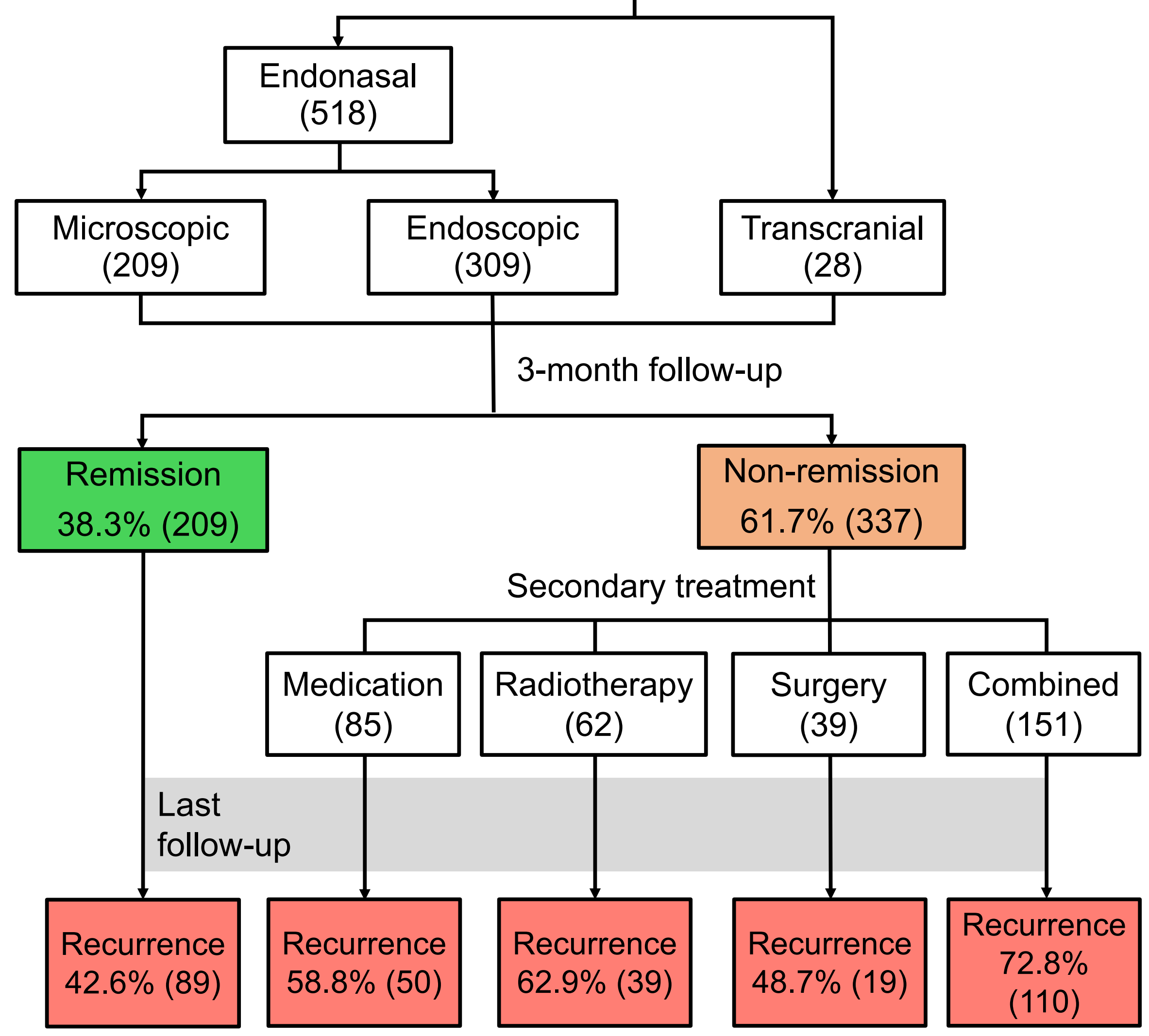


A Tumor Size By Knosp Class

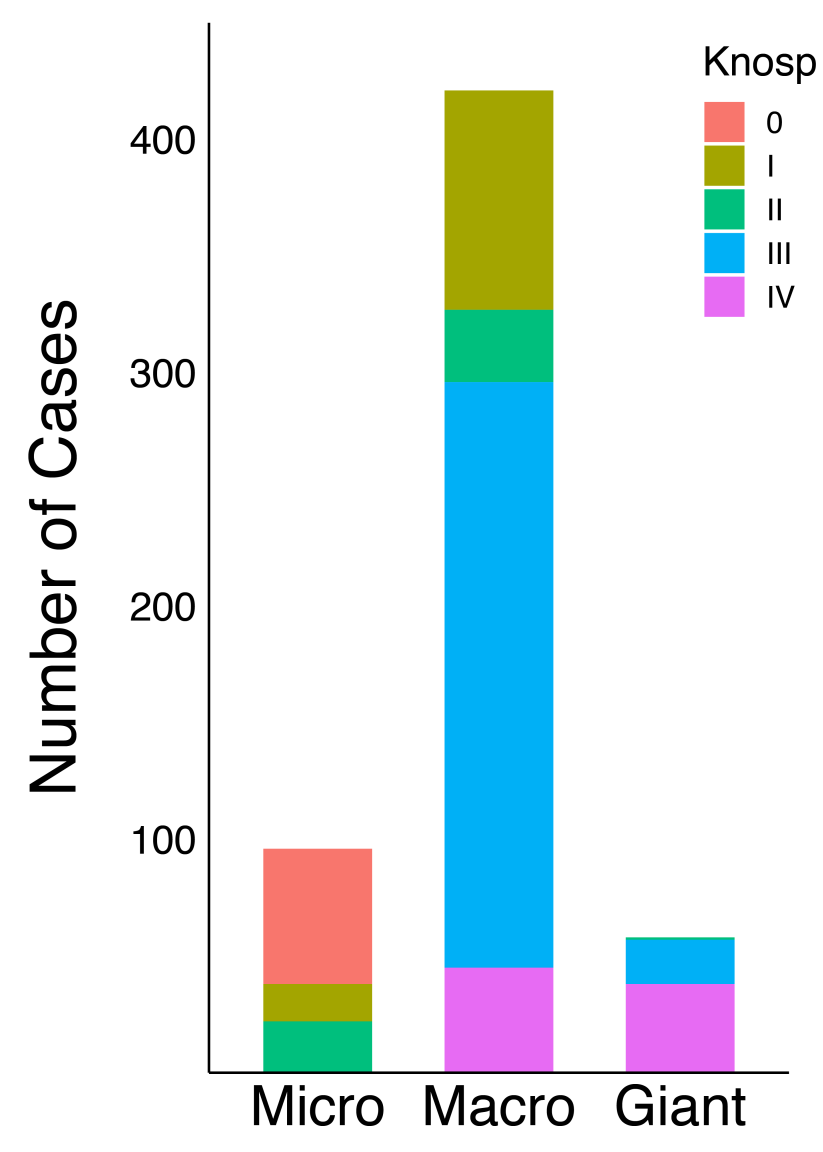

B

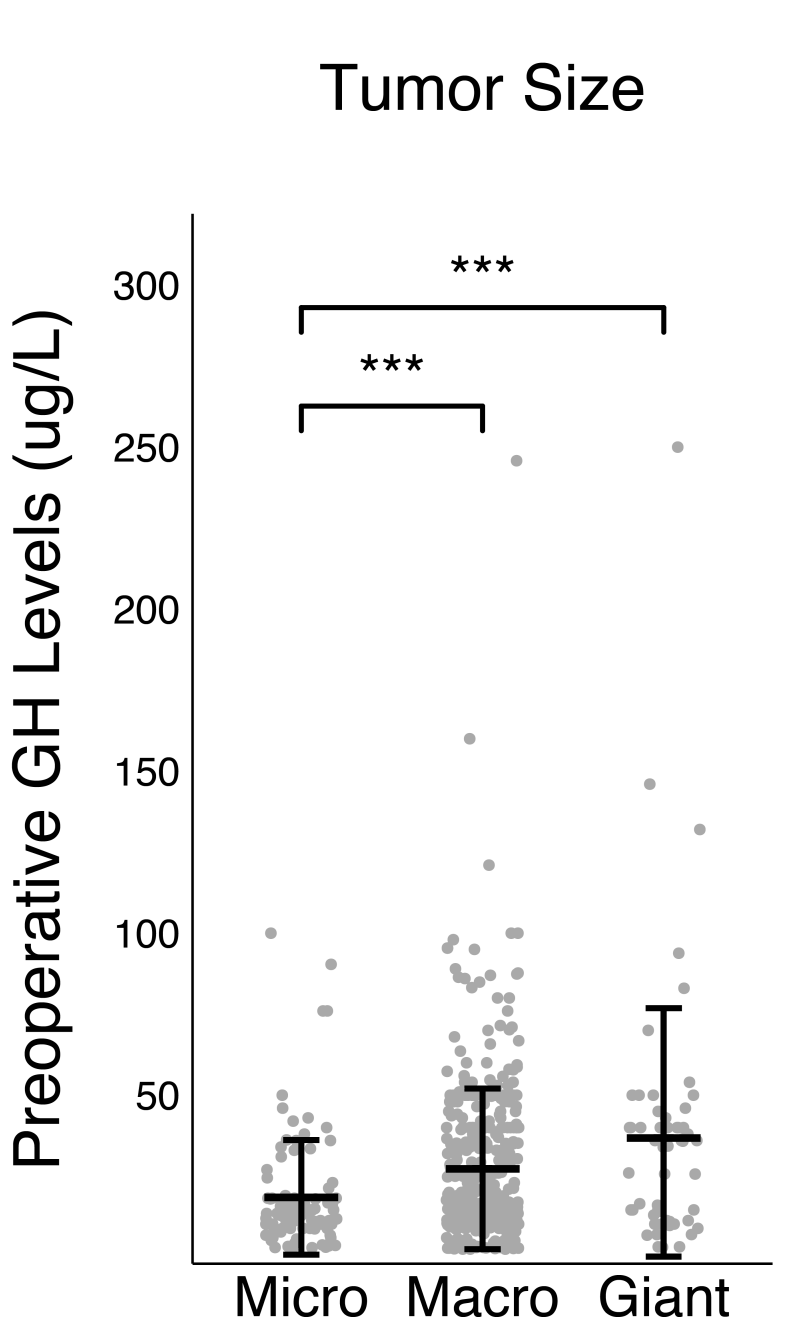

C

Knosp Classification

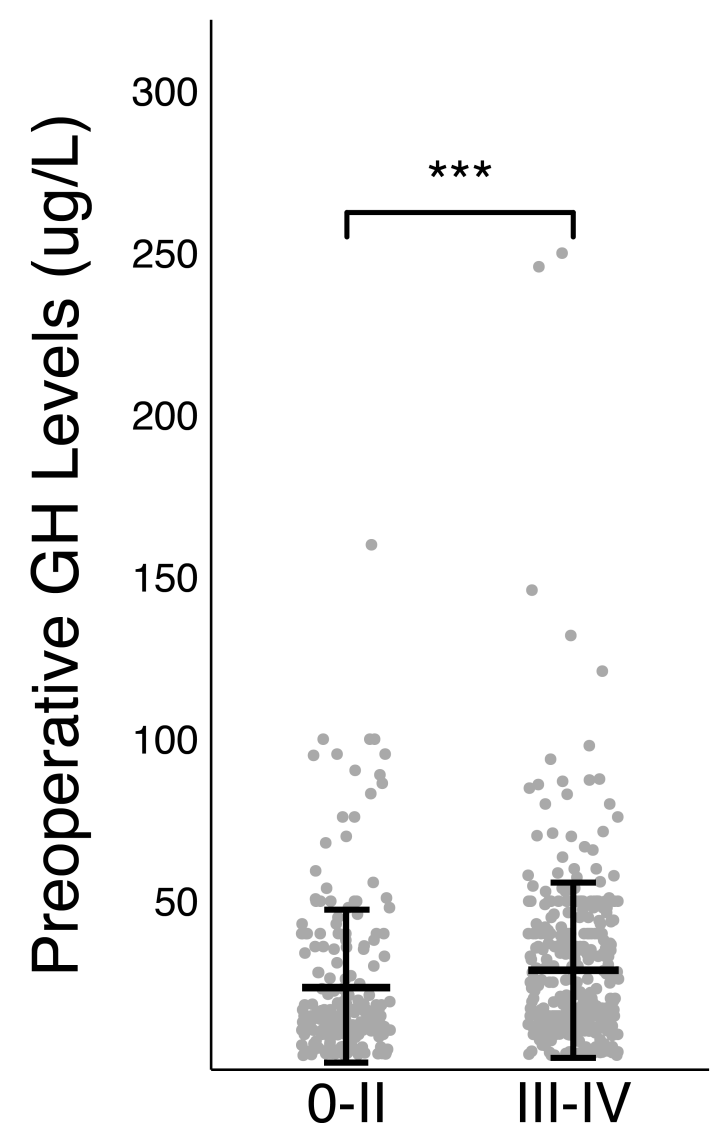


Preoperative GH Levels $12-28(\mu \mathrm{g} / \mathrm{L})^{a}$

Preoperative GH Levels $>28(\mu \mathrm{g} / \mathrm{L})^{a}$

Macroadenoma $^{b}$

Giant adenoma $^{b}$

Knosp III-IV ${ }^{c}$

Preoperative medication

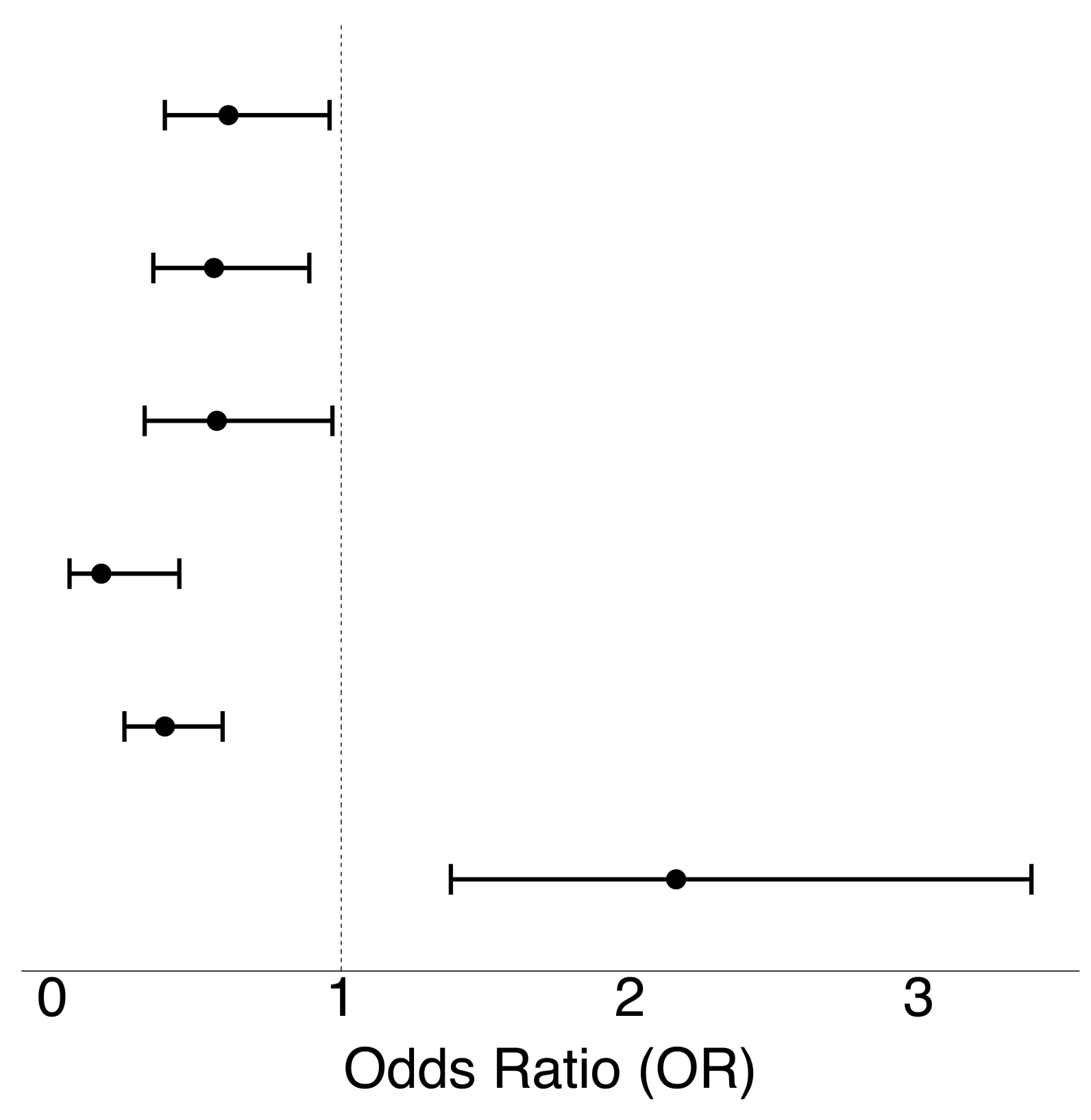

